\title{
KOMPETENSI KEPRIBADIAN GURU DAN PENGARUHNYA TERHADAP MOTIVASI BELAJAR BIDANG STUDI PAI SISWA KELAS X DI SMA MA'ARIF BULAKAMBA KABUPATEN BREBES
}

\author{
Mohammad Fadilah, Saefudin Zuhri,Iwan \\ Fakultas Ilmu Tarbiyah dan Keguruan \\ Institut Agama Islam Negeri Syekh Nurjati Cirebon \\ Email: mfadilah028@gmail.com
}

\begin{abstract}
ABSTRAK
Kepribadian adalah sebuah kata yang menandakan ciri pembawaan dan pola kelakuan seseorang yang khas bagi peribadi itu sendiri. Kepribadian melipti tingkah laku, cara berfikir, perasaan, gerak hati, usaha, aksi, tanggapan terhadap kesempatan, tekanan dan cara sehari-hari dalam berintraksi dengan orang lain. Jika unsur-unsur kepribadian ini menyatakan diri dalam kombinasi yang berulang-ulang secara khas dan dinamis maka hal demikian dikenal dengan nama gaya kepribadian. Keberhasilan sebuah pendidikan tidak terlepas dari kepribadian guru yang akan berdampak pada motivasi belajar siswa. Karena guru sebagai suri teladan bagi siswa. Akan tetapi pada kenyataanya masih banyak siswa yang belum sesuai harapan.

Tujuan penelitian ini adalah: 1) Memperoleh tentang kepribadian guru bidang studi Pendidikan Agama Islam di SMA Ma'arif Bulakamba Kabupaten Brebes. 2) Memperoleh tentang motivasi belajar siswa di SMA Ma'arif Bulakamba kabupaten Brebes. 3) Memperoleh bagaimana kompetensi kepribadian guru dan pengaruhnya terhadap motivasi belajar bidang studi PAI siswa kelas X di SMA Ma'arif Bulakamba Kabupaten Brebes.

Penelitian ini berawal dari kerangka pemikiran bahwa kompetensi kepribadian guru dan motivasi belajar saling mempengaruhi antara pendidik dan peserta didik untuk menumbuhkan motivasi belajar bidang studi PAI di SMA Ma'arif Bulakamba Kabupaten Brebes.

Penelitian ini merupakan penelitian kuantitatif. Teknik pengumpulan data yang digunakan dalam penelitian ini adalah observasi, wawancara, angket, dan dokumentasi. Teknik Analisis data yang digunakan pada penelitian ini adalah analisis kuantitatif, dan uji korelasi.
\end{abstract}

Kesimpulan hasil penelitian ini yaitu, kompetensi kepribadian guru di SMA Ma'arif Bulakamba Kabupaten Brebes, memperoleh rata-ratanya 2289 termasuk dalam wilayah 
kadang-kadang dengan nilai 67\%. Motivasi belajar SMA Ma'arif Buakamba Kabupaten Brebes, memperoleh rata-ratanya 1575 termasuk dalam wilayah Kadang Kadang dengan nilai 58\%. Hubungan kompetensi kepribadian guru dan pengaruhnya terhadap motivasi belajar menunjukkan nilai korelasi yang mencapai $\boldsymbol{r}_{\boldsymbol{x y}}=\mathbf{0 , 0 5 0 \%}$ yang menunjukkan pada korelasi yang lemah atau rendah karena berada pada interval 0,40-0,70 dan nilai kontribusi determinasi yaitu dengan nilai prosentase sebesar 0,25\% sedangkan sisanya sebesar 99,75\% dipengaruhi faktor lain.

\section{Kata Kunci: Kepribadian dan Motivasi Belajar}




\section{A. Pendahuluan}

Guru merupakan salah satu komponen terpenting dalam dunia pendidikan di dalam termasuk kompetensi guru dalam mengelola pembelajaran peserta didik perlu mendapatkan perhatian yang serius. hal ini penting karena ruh pendidikan sesungguhnya terletak di pundak guru, bahkan baik buruknya atau berhasil tidaknyapendidikan hakikatnya ada di tangan guru. Sebab sosok guru memiliki peranan yang setrategis dalam mengukir peserta didik menjadi pandai, cerdas, bermoral, dan berpengetahuan luas. disisi lain, guru tidak saja berfungsi sebagai prantransfer ilmu tetapi juga sebagai pendidik, pengajar, pembimbing, pengaruh, melatih menilai dan mengavaluasi peserta didik. Dengan demikian, pendidikan pada dasarnya merupakan usaha sadar untuk mengembangkan kepribadian dan kemampuan individu kearah kedewasaan. Pendidikan juga merupakan suatu komponen yang sangat penting bagi manusia, karena pendidikan sebagai usaha sadar untuk menyiapkan peserta didik dalam peranya di masa yang akan datang selain itu pendidikan memegang posisi kunci atau rendahnya kebudayaan suatu masyarakat, menuju atau mundurnya tingkat kebudayaan suatu masyarakat dan negara sebagian besar bergantung kepada pendidikan dan pengajaran yang diberikan oleh guru. Dengan kata lain tinggi rendahnya suatu bangsa tergantung pada mutu pendidikan dan pengajaran yang diberikan oleh guru. Dengan kata lain, tinggi rendahnya sesuatu bangsa tergantung pada mutu pendidikannya. ${ }^{1}$

Kepribadian adalah sebuah kata yang menandakan ciri pembawaan dan pola kelakuan seseorang yang khas bagi peribadi itu sendiri. Kepribadian melipti tingkah laku, cara berfikir,perasaan, gerak hati, usaha, aksi, tanggapan terhadap kesempatan, tekanan dan cara sehari-hari dalam berintraksi dengan orang lain. Jika unsur-unsur kepribadian ini menyatakan diri dalam kombinasi yang berulang-ulang secara khas dan dinamis maka hal demikian dikenal dengan nama gaya kepribadian.

Kepribadian adalah khas bagi setiap pribadi, sedangkan gaya kepribadian bisa dimiliki oleh orang lain yang juga menunjukan kombinasi yang berulang-ulang secara khas dan dinamis dari ciri pembawaan dan pola kelakuan yang sama

Berdasarkan peraturan pemerintah No. 19 tahun 2005 tentang Standar Nasional Pendidikan seorang guru harus mempunyai kualifikasi akademik yang dibuktikan dengan sertifikat keahlian yang diperoleh melalui sertifikasi sebagai penguasaan

\footnotetext{
${ }^{1}$ Ngalim Purwanto, Psikologi Pendidikan (Bandung: Remaja Rosdakarya, 2013) hal. 138
} 
kompetensi. Pada kompetensi kepribadian, setiap guru harus memiliki pribadi yang mantab, stabil, berwibawa, dewasa, arif dan berakhlak mulia. Pada kompetensi profesional, guru dituntut memiliki wawasan keilmuan yang luas dan mendalam, pada kompetensi pedagogik, guru menguasai ilmu pendidikan, antara lain memahami karakter siswa, perancangan pembelajaran, pelaksanaan pembelajaran, evaluasi pembelajaran dan pengembangan peserta didik. Sedangkan pada kompetensi sosial, guru harus mampu berkomunikasi efektif dan bersosialisasi dengan benar dan baik.

Dalam proses belajar mengajar, setiap guru mempunyai keinginan agar siswanya berhasil dalam mencapai hasil belajar yang baik. Untuk mewujudkannya, diperlukan penegakan disiplin bagi siswa yang melanggar tata tertib yang berlaku di sekolah, sehingga diharapkan siswa dapat berperilaku yang baik dan berhasil dalam proses pembelajaran. Sekolah menjadikan disiplin sebagai syarat dalam pembentukan sikap dan perilaku siswa. Dengan disiplin akan tumbuh kepatuhan, kemandirian, keteraturan, menumbuhkan sikap percaya diri dan peduli terhadap orang lain. Disiplin juga dapat membuat siswa menjadi lebih tertib dan teratur dalam menjalankan kehidupan sehari-hari.

Dalam rangka meningkatkan mutu pembelajaran dan pendidikan dan pendidikan tidak bergantung kepada satu komponen saja misalnya guru, melainkan sebagai sebuah sistem kepada beberapa komponen antara lain brupa program kegiatan pemblajaran murid, sarana dan prasarana pembelajaran, lingkungan masyarakat, dan kepemimpinan kepala sekolah. Namun semua komponen yang teridentifikasi di atas tidak akan berguna bagi terjadinya peroleh an pengalaman belajar maksimal bagi pesrta didik jika tidak didukung oleh keberadaan guru sebagai pendidik sangat menentukan, sehingga guru menjadi sala satu faktor yang paling penting, pertama dan utama dalam menentukan, sehingga para guru menjadi salah satu faktor yang paling penting, pertama dan utama dalam menentukan berhasilnya proses belajar mengajar di dalam kelas.

Guru memegang peranan dalam penentu berhasil tidaknya pencapaian tujuan suatu proses pembelajaran, sekalipun proses pembelajaran telah menggunakan berbagai model pendekatan dan metode yang lebih memberi peluang bagi siswa aktif. Kedudukan dan peran guru tetap penting dan menentukan, untuk itu mutu pendidikan sangat ditentukan oleh kemampuan yang dimiliki oleh guru dalam menjalankan tugasnya. Hal ini menandai bahwa peranan guru tidak dapat digantikan oleh siapapun juga. Guru berusaha menempatkan siswa sebagai subjek belajar, guru sebagai pelayan fasilitator dan mitra siswa agar siswa dapat mengalami proses belajar bermakna." 
Guru merupakan sosok yang begitu dihormati, guru sangat berperan dalam membantu perkembangan peserta didik, untuk menentukan tujuan hidupnya secara optimal. Ketika orang tua mendaftarkan ananknya kesekolah, pada saat itu juga ia menaruh harapan terhadap guru, agar anaknya berkembang secara optimal. Dengan demikian betapa pentingya peranan guru dalam proses belajar mengajar, disamping memberikan pengetahuan kepada siswa guru juga mempunyai tujuan untuk menjadikan saubjek didik mempunyai sikap dan tingkah laku yang sesuai dengan jiwa pancasila.

Oleh karena itu, guru harus memiliki kompetensi dasar dalam mencerdaskan anak didiknya, adalah" suatu hal yang menggambarkan kualifikasi atau kemampuan seseorang, baik yang kualitatif maupun yang kuantitatif." menjelaskan bahwa kompetensi juga diartikan sebagai pengetahuan, keterampilan dan kemampuan yang dikuasai oleh seseorang yang telah menjadi bagian dari dirinya sehingga ia dapat melakukan perilakuperilaku kognitf, afektif, psikomotorik dengan sebaik-baiknya ".

Faktor yang mempengaruhi belajar ada dua yaitu faktor intern dan faktor ekstern. Faktor intern yaitu faktor yang berasal dari dalam diri individu yang terdiri dari aspek jasmaniah (faktor kesehatan, cacat tubuh), aspek psikologis (inteligensi, perhatian, motif, bakat, kematangan, minat, kesiapan) dan aspek kelelahan. Faktor ekstern adalah faktor yang berasal dari luar diri individu yang terdiri dari faktor lingkungan keluarga, lingkungan sekolah dan lingkungan masyarakat.

Dalam proses pembelajaran, selain kajian teori belajar dan teori pembelajaran, ada hal lain yang juga penting untuk di kaji korelasinya dengan proses belajar dan pembelajaran, yaitu berkenaan dengan motivasi. Bagaimana peran motivasi dalam belajar dan pembelajaran.

Secara umum terdapat dua peranan penting motivasi dalam belajar, pertama, motivasi merupakan daya penggerak psikis dalam diri siswa yang menimbulkan kegiatan belajar, menjamin kelangsungan belajar demi mencapai satu tujuan. Kedua, motivasi memegang peranan penting dalam memberikan gairah, semangat dan rasa senang dalam belajar, sehingga siswa yang mempunyai motivasi tinggi mempunyai energi yang banyak untuk melaksanakan kegiatan belajar. ${ }^{2}$

\footnotetext{
${ }^{2}$ Eveline Siregar dan Hartini Nara, Teori belajar dan Pembelajaran. (Bogor: Ghalia indonesia, 2011), 51 .
} 
Dari paparan di atas maka penulis merumuskan masalah, adakah pengaruh Kompetensi Kepribadian guru terhadap motivasi belajar bidang studi PAI siswa kelas x di SMA ma'arif Bulakamba Kabupaten Brebes?

\section{B. Kompetensi Kepribadian Guru dan Pengaruhnya Terhadap Motivasi Belajar Bidang Studi PAI}

Penelitian ini dilakukan di SMA Ma'Arif Bulakamba. Yang berada dilokasi yang cukup strategis yakni bertempat di Jl. Raya Luwungragi Kecamatan Bulakamba Kabupaten Brebes. Adapun waktu penelitian dilaksanakan pada semester Genap, yaitu dimulai dari bulan April sampai dengan Juni 2017. Untuk lebih jelasnya dibawah ini:

Waktu penelitian berdasarkan Surat Keputusan oleh Dekan Fakultas Ilmu Tarbiyah dan Keguruan (FITK) Nomor: 2224/ In. 08/ F. I.I/ PP.009/04/2017 terhitung mulai tanggal 04 Januari sampai dengan 31 Maret. Penelitian ini dilakukan selama kurang lebih 3 bulan.

Penelitian ini termasuk jenis penelitian kuantitatif. Penelitian kuantitatif adalah jenis penelitian yang mengandalkan pada pengindraan empiris atau pengolahan data melalui hitungan angka dalam matematika. Penelitian kuantitatif juga dapat diartikan sebagai penelitian dengan menggunakan analisis data berupa perhitungan secara matematis. Ciri utamanya adalah menggunakan data statistik karena menggunakan atau menerapkan rumus dan cara kerja ilmu statistik.

Penelitian kuantitatif didasari oleh filsafat positivisme yang menekankan fenomena-fenomena objektif dan dikaji secara kuantitatif. Maksimalisasi objektivitas desain penelitian ini dilakukan dengan menggunakan angka-angka, pengolahan statistik, struktur dan percobaan terkontrol. Ada beberapa metode penelitian yang dapat dimasukkan kedalam penelitian kuantitatif yang bersifat noneksperimental, yaitu metode: deskriptif, survai, ekspos fakto, komparatif, korelasional dan penelitian tindakan. ${ }^{3}$

\footnotetext{
${ }^{3}$ Nana Saodih Sukamdinata, Landasan Psikologi Proses Pendidikan (Bandung : PT Remaja Rosda Karya, 2006), 53.
} 
Berdasarkan pengertian penelitian kuantitatif di atas peneliti dapat menyimpulkan bahwa penelitian kuantitatif adalah penelitian yang pengumpulan datanya menggunakan angka-angka atau statistik karena pada saat mengerjakan atau mengumpulkan data menggunakan, menerapkan, mengolah rumus, selain itu mengutamakan desain dan metode kerja yang ketat agar data yang didapatkan akurat.

\section{Sumber Data}

Sumber data teoritik, yaitu data yang diperoleh dari buku-buku yang ada hubungannya dengan kompetensi kepribadian guru PAI dan motivasi belajar siswa untuk dijadikan sebagai sumber rujukan.

Sumber data empirik, yaitu data yang diperoleh dari lokasi penelitian di SMA Ma'arif Bulakamba Kabupaten Brebes..

\section{Desain Penelitian}

Desain penelitian yang dilakukan ada beberapa tahap, yaitu tahap persiapan, tahap pelaksanaan / pengumpulan data, tahap pengolahan data, dan tahap penulisan laporan hasil penelitian. Adapun rincian masing-masing tahapan ada dibawah ini:

a. Tahap persiapan, meliputi: telaah dokumen, penyusunan proposal, seminar proposal, revisi proposal dan revisi IPD.

b. Tahap pelaksanaan/pengumpulan data, dalam pengumpulan data sebagai bahan dengan cara penyebaran angket/kuesioner, observasi, dokumentasi dan wawancara. Penyebaran angket diberikan kepada responden yang telah ditentukan.

c. Tahap pengolahan data, pengolahan data dilakukan setelah pengambilan atau pengumpulan data sudah diperoleh dan mencapai tahap akhir.

Tahap penulisan laporan hasil penelitian yang telah diperoleh dari penyebaran angket/kuesioner

\section{a. Populasi dan Sampel}

\section{1) Populasi}

Populasi adalah wilayah generalisasi yang terdiri atas: obyek/subyek yang mempunyai kualitas dan karakteristik tertentu yang ditetapkan oleh peneliti untuk dipelajari dan kemudian ditarik kesimpulannya, ${ }^{4}$

\footnotetext{
${ }^{4}$ Sugiyono, Metode Penelitian Pendidikan (Bandung: Alfabeta, 2007), 80.
} 
Populasi merupakan wilayah generalisasi yang terdiri dari objek atau subjek yang memiliki kualitas dan karakteristik tertentu yang ditetapkan oleh peneliti untuk dipelajari dan kemudian ditarik kesimpulan dari penelitian tersebut. ${ }^{5}$ Selain pendapat diatas, ada pendapat lain yang mengartikan populasi secara lebih singkat yakni, populasi adalah keseluruhan subjek yang diteliti. ${ }^{6}$ Dalam penelitian ini yang menjadi populasi dari subyek penelitian ini adalah kompetensi kepribadian guru dan motivasi belajar, dengan jumlah sebagai berikut.

Tabel 3.2

Jumlah Siswa

Tahun Pelajaran 2016 / 2017

\begin{tabular}{|l|l|c|c|c|}
\hline \multirow{2}{*}{ No } & \multirow{2}{*}{ Kelas } & \multicolumn{2}{|c|}{ Jenis Kelamin } & \multirow{2}{*}{ Jumlah } \\
\cline { 3 - 4 } & & $\mathbf{L}$ & $\mathbf{P}$ & \\
\hline 1. & Kelas X-IPA & 17 & 16 & 33 Siswa \\
\hline 2. & Kelas X-IPS & 10 & 14 & 24 siswa \\
\hline 2. & Kelas XI-IPA & 11 & 21 & 32 Siswa \\
\hline 3. & Kelas XI-IPS & 18 & 14 & 32 Siswa \\
\hline 4. & Kelas XII-IPA & 12 & 2 & 14 Siswa \\
\hline 5. & Kelas XII-IPS & 4 & 5 & 9 Siswa \\
\hline
\end{tabular}

Tabel 3.3

Jumlah Siswa Kelas X SMA Ma'arif Bulakamba Kabupaten Brebes

\begin{tabular}{|c|c|c|}
\hline Kelas & Jurusan) & Jumlah siswa \\
\hline \multirow{2}{*}{$\mathrm{X}$} & IPA & 33 \\
\cline { 2 - 3 } & IPS & 24 \\
\hline \multicolumn{2}{|c|}{ Jumlah } & $\mathbf{5 7}$ iswa \\
\hline
\end{tabular}

\section{2) Sampel}

${ }^{5}$ Sugiyono, Metode Penelitian Pendidikan, 61.

${ }^{6}$ Suharsimi Arikunto, Prosedur Penelitian; Suatu Pendekatan Praktik (Jakarta: PT Rineka Cipta, 2006), 130 . 
Sampel merupakan bagian dari populasi yang memiliki ciri-ciri atau keadaan tertentu yang akan diteliti. Atau, sampel dapat didefinisikan sebagian anggota populasi yang dipilih dengan menggunakan prosedur tertentu sehingga diharapkan dapat mewakili populasi.

Teknik sampling yang digunakan oleh peneliti adalah cluster sampling. Menurut Sugiyono cluster sampling yaitu teknik yang digunakan untuk menentukan sampel bila objek yang akan diteliti terlalu luas. ${ }^{7}$

Sampel menurut Suharsimi Arikunto yaitu sebagian atau wakil acak yang menyatakan bahwa untuk sekedar ancer-ancer, maka apabila subjeknya kurang dari 100 lebih baik diambil semua, tetapi jika jumlah subjeknya lebih besar, dapat diambil $10-15 \%$ atau $20-25 \%$ lebih. $^{8}$

Dari pendapat tersebut, maka sampel diambil dari Jumlah Siswa SMA Ma'arif Bulakamba Kabupaten Brebes Kelas X yang berjumlah 57 orang, sehingga sampel yang diperoleh sebanyak 57 orang.

\section{b. Variabel Penelitian}

Penelitian ini memiliki dua varabel, yaitu variabel independen dan variabel dependen. Variabel independen (variable bebas) merupakan variabel yang mempengaruhi variabel lain, yang pada umumnya berada dalam urutan tata waktu yang terjadi lebih dulu. Variabel ini biasanya disimbolkan dengan variabel "x", sedangkan yang dimaksud dengan variabel dependen (variable terikat) merupakan variabel yang diakibatkan atau dipengaruhi oleh variabel bebas. Penelitian ini biasanya disimbolkan dengan variabel " $y$ ",.

Dalam penelitian ini yang menjadi variabel independen adalah kompetensi kepribadian guru PAI sebagai variabel $\mathrm{X}$ dan variabel dependennya adalah motivasi belajar siswa sebagai variabel Y.

\section{c. Instrumen Penelitian}

\section{1) Kisi-kisi Penelitian}

\section{a) Definisi Konseptual}

Definisi Konseptual Variabel X kompetensi kepribadian, yaitu "kemampuan kepribadian yang (a)berakhlak mulia,(b) mantap,stabil, dan dewasa,(c) arif dan

\footnotetext{
${ }^{7}$ Sugiyono, Metode Penelitian Pendidikan, 121.

${ }^{8}$ Suharsimi Arikunto, Prosedur Penelitian Suatu Pendekatan Praktik, 134.
} 
bijaksana(d) menjadi teladan,(e) mengevaluasi kinerja sendiri(f) mengembangkan diri, dan(g) Relegius.

Proses pembelajaran khususnya di SMA Ma'arif Bulakamba bidang Studi PAI merupakan proses transformasi ilmu-ilmu pengetahuan dan nilai-nilai pada diri anak didik yang mempunyai segala aspek kegiatan-kegiatan pendidikan, pembinaan, proses ataupun bimbingan yang berhubungan dengan agama untuk menyempurnakan hidup dalam segala bidangnya.

Adapun indikator-indikator yang terdapat dalam proses pembelajaran di SMA Ma'arif Bulakamba adalah sekurang-kurangnya meliputi hal-hal berikut: Memiliki kepribadian yang berakhlak mulia, mantap stabil dan dewasa, arifdan, berwibawa, menjadi teladan, mengevaluasi kinerja sendiri, mengembangkan diri dan relegius. ${ }^{9}$ Definisi Konseptual Variabel Y

Motivasi belajar siswa adalah kecenderungan, rasa berlebih yang dapat memotivasi seseorang untuk melakukan sesuatu dalam mencapai sebuah tujuan yang diinginkan dan mendapatkan posisi yang diharapkan, dan ditandai dengan perubahan tenaga, emosi dan rasa ingin yang berlebih.

Adapun indikator-indikator yang terdapat dalam motivasi belajar yaitu tekun, ulet, minat, dan lebih suka bekerja sendiri dalam proses pendidikan. ${ }^{10}$

\section{b) Definisi Operasional}

Dalam penjabaran operasinal ini, perlu dijelaskan terlebih dahulu maksud dari definisi operasional itu sendiri. Operasional adalah tindakan penelitian yang dilakukan oleh peneliti pada suatu objek yakni responden/informen untuk mendapatkan data terkait dengan variabel yang telah ditentukan. Pada penelitian ini, ada dua variabel yang diteliti yakni:

\section{Definisi Operasional Variabel X}

Skor angket yang diberikan kepada masyarakat terhadap proses pembelajaran di SMA Ma'arif Bulakamba dengan melalui pengisian angket/kuesioner yang telah diberikan kepada masing-masing siswa sebanyak 15 butir soal pernyataan berkaitan dengan Kompetensi kepribadian guru PAI di SMA MA'arif Bulakamba. Tentunya angket/kuesioner yang disebarkan kepada siswa SMA Ma'arif Bulakamba disesuaikan dengan indikator-indikator yang terkait dengan kompetensi

\footnotetext{
${ }^{9}$ Jejen Musfah, Peningkatan Kompetensi Guru (Jakarta: Kencana Prenada Media Group, 2012), 42.

${ }^{10}$ Sardiman, Intraksi Dan Motivasi Belajar-Mengajar (Jakarta, 2011), 83.
} 
kepribadian guru di SMA Ma'arif Bulakamba, yakni: memiliki kepribadian yang berakhlak mulia, mantap,stabil dan dewasa, memiliki kepribadian yang arif, bijaksana menjadi teladan, mengevaluasi kinerja sendiri, mengembangkan diri dan relegius.

\section{Definisi Operasional Variabel Y}

Skor angket yang diberikan kepadaSiswa SMA Ma'arif Bulakamba Kabupaten Brebes, hampir sama dengan varibel X. Pada angket/kuesioner variabel Y ini, memiliki 15 butir soal pernyataan yang harus diisi oleh masyarakat terkait dengan motivasi belajar siswa itu sendiri. Tentunya angket/kuesioner yang diberikan kepada siswa SMA Ma'arif Bulakamba Kabupaten Brebes, telah disesuai kan dengan indikator-indikator yang memiliki kaitan dengan motivasi belajar siswa, yakni:tekun, ulet, minat, lebih senang bekerja sendiri dalam proses pendidikan.

Tabel 3.4

Hubungan Kompetensi Kepribadian Guru dan Pengaruhnya terhadap Motivasi Belajar Bidang Studi PAI Siswa Kelas X di SMA Ma'arif Bulakamba Kabupaten Brebes

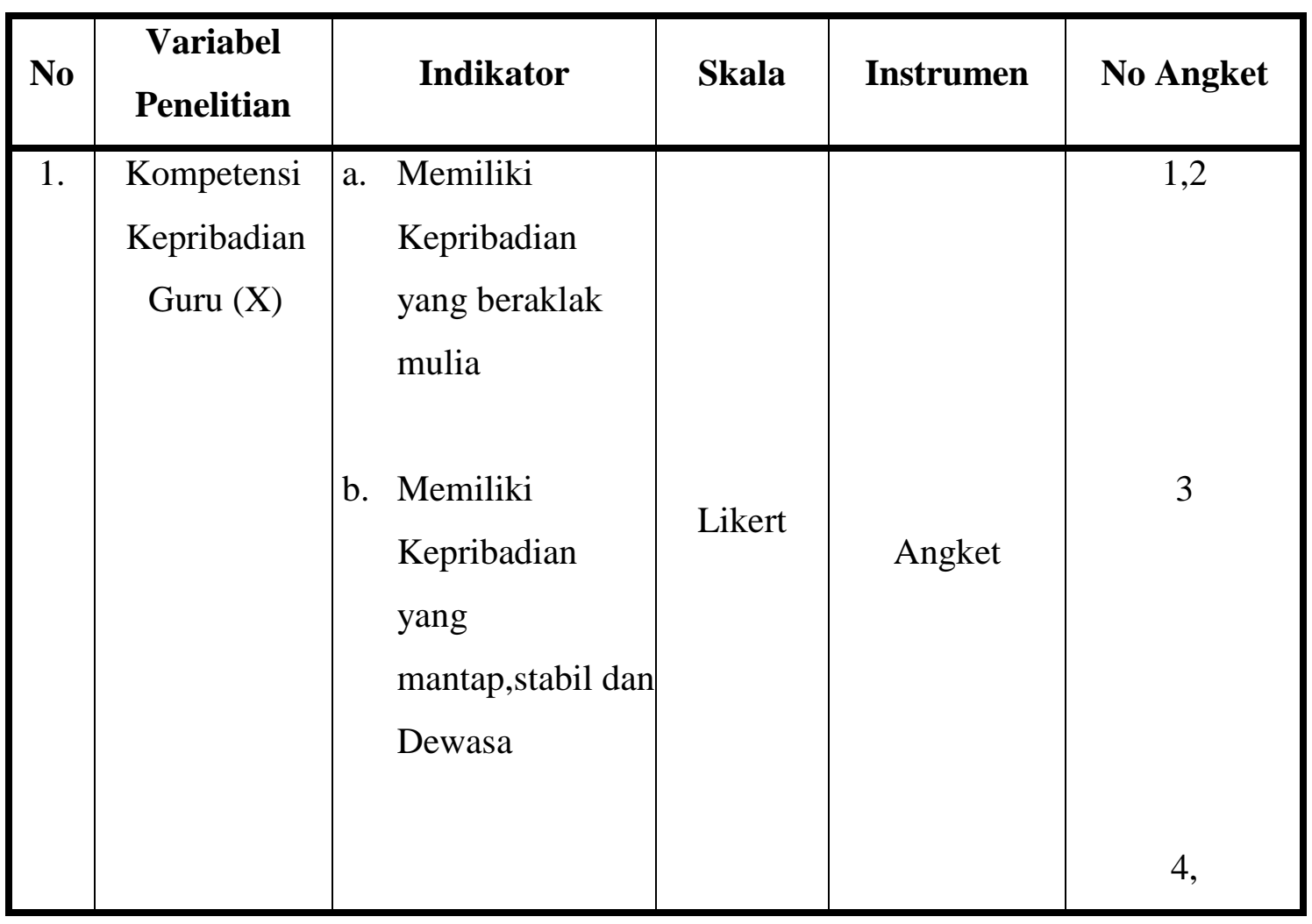




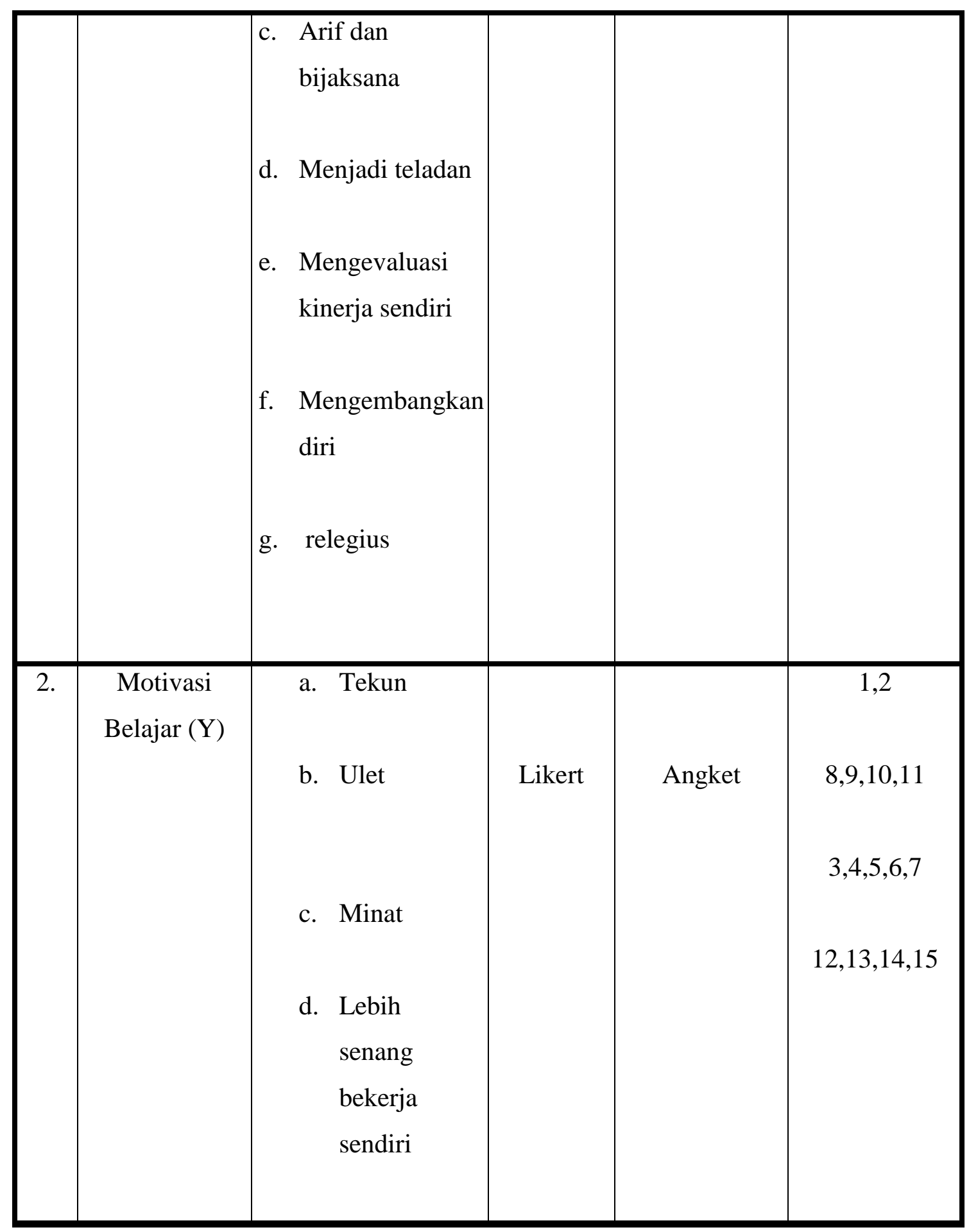

Teknik Penskoran :

Skor 4 (empat) untuk jawaban atau pilihan selalu(SL)

Skor 3 (tiga) untuk jawaban atau pilihan sering (SR)

Skor 2 (dua) untuk jawaban atau pilihan kadang - kadang(KK)

Skor 1 (satu) untuk jawaban atau pilihan tidak pernah (TP) 


\section{2) Teknik Pengumpulan Data}

Metode pengumpulan data adalah suatu cara yang dilakukan untuk memperoleh data dalam penelitian. Pengumpulan data dapat dilakukan dalam berbagai setting, berbagai sumber dan berbagai cara. Bila dilihat dari settingnya, data dapat dikumpulkan pada setting alamiah, laboratorium, dan lain-lain. Dilihat dari sumber datanya, maka pengumpulan data dapat menggunakan sumber primer, dan sumber sekunder. Selanjutnya dilihat dari segi cara atau teknik pengumpulan data, dapat dilakukan dengan interview (wawancara), kuesioner (angket), observasi (pengamatan), dan gabungan ketiganya. ${ }^{11}$

Dalam penilitian ini teknik pengumpulan data yang digunakan adalah dengan melakukan wawancara, membagikan angket, dan melakukan observasi dan dokumentasi.

1. Wawancara

Wawancara digunakan sebagai teknik pengumpulan data apabila peneliti ingin melakukan studi pendahuluan untuk menemukan permasalahan yang harus diteliti, dan apabila peneliti ingin mengetahui hal-hal dari responden yang lebih mendalam dan jumlah respondennya sedikit/kecil.

Metode wawancara dalam penelitian ini digunakan untuk mengetahui beberapa hal yang tidak diperoleh dari hasil pembagian angket. Wawancara dilakukan pada siswa dan Guru untuk mengetahui Kompetensi Kepribadian guru Dan motivasi Belajar.

\section{Kuesioner (Angket)}

Kuesioner merupakan teknik pengumpulan data yang dilakukan dengan cara memberi seperangkat pertanyaan atau pernyataan tertulis kepada responden untuk dijawabnya. $^{12}$

Angket akan disebarkan kepada seluruh siswa kelas X SMA Ma'ari bulakamba, untuk Angket ini dijadikan data untuk mengetahui Hubungan kompetensi kepribadian guru dengan motivasi belajar siswa kelas X di SMA Ma'arif Bulakamba Kabupaten Brebes.

\section{Tabel. 3.5}

Skor Jawaban Angket

\section{\begin{tabular}{|l|l|}
\hline Jawaban alternative & Skor pernyataan positif \\
\hline
\end{tabular}}

\footnotetext{
${ }^{11}$ Sugiyono, Metode Penelitian Pendidikan,193.

${ }^{12}$ Sugiyono, Metode Penelitian Pendidikan, 199.
} 


\begin{tabular}{|l|c|}
\hline Selalu & 4 \\
\hline Sering & 3 \\
\hline Kadang - kadang & 2 \\
\hline Tidak pernah & 1 \\
\hline
\end{tabular}

\section{Observasi}

Observasi sebagai teknik pengumpulan data mempunyai ciri yang spesifik bila dibandingka dengan teknik yang lain, yaitu kuesioner dan wawancara. Kalau wawancara kuesioner selalu berkomunikasi dengan orang maka observasi tidak terbatas pada orang tetapi juga dengan obyek-obyek lainnya. Observasi digunakan bila obyek penelitian bersifat perilaku manusia, proses kerja, gejala alam, responden kecil. ${ }^{13}$

Metode observasi digunakan untuk mengamati kompetensi kepribadian guru dan pengaruhnya terhadap motivasi belajar bidang studi PAI Siswa kelas X SMA Ma'arif Buakamba Kabupaten Brebes

\section{Dokumentasi}

Dokumentasi yaitu suatu metode pengumpulan data yang bersumber dari tulisantulisan, arsip-arsip atau sumber data lainnya yang berhubungan dengan kondisi objek penelitian yaitu profil dan sejarah SMA Ma'arif Bulakamba Kabupaten Brebes

\section{3) Teknik Analisis Data}

Setelah data diperoleh, selanjutnya diadakan analisis terhadap data yang berhubungan dengan penelitian kompetensi kepribadian guru dan pengaruhnya terhadap motivasi belajar bidang studi PAI siswa kelas X SMA Ma'arif Bulakamba Kabupaten Brebes. Adapun alat analisis yang digunakan dalam penelitian ini meliputi:

1. Deskriptif Kuantitatif

Menggunakan data interval sebagai analisis data penelitian kemudian dihitung rata-rata jawaban berdasarkan skoring setiap jawaban dari responden, yakni:

Jumlah skor untuk berapa responden yang menjawab SL x 4

Jumlah skor untuk berapa responden yang menjawab SR x 3

Jumlah skor untuk berapa responden yang menjawab KK x 2

Jumlah skor untuk berapa responden yang menjawab TP x1

Kemudian, dapat digambarkan secara kontinum seperti gambar berikut:

${ }^{13}$ Sugiyono, Metode Penelitian Pendidikan, 204. 
Nilai Interval Angket

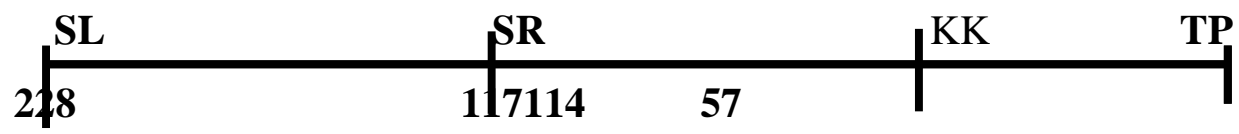

Gambar 3.1 Gambar penskoran responden

2. Korelasi Product Moment

Rumus korelasi product moment, yaitu:

$$
r_{x y}=\frac{N \cdot \Sigma \mathrm{XY}-(\Sigma \mathrm{X})(\Sigma \mathrm{Y})}{\sqrt{\left\{N \cdot \Sigma \mathrm{X}^{2}-(\Sigma \mathrm{X})^{2}\right\}\left\{N \cdot \Sigma Y^{2}-(\Sigma Y)^{2}\right\}}}
$$

Keterangan:

$r_{x y}=$ Angka indeks korelasi antara variabel $\mathrm{X}$ dan $\mathrm{Y}$

$\Sigma \mathrm{XY}=$ Jumlah hasil perkalian antara skor $\mathrm{X}$ dan skor $\mathrm{Y}$

$\Sigma \mathrm{X}=$ Jumlah total variabel $\mathrm{X}$

$\Sigma \mathrm{Y}=$ Jumlah total variabel $\mathrm{Y}$

$\Sigma \mathrm{X}^{2} \quad=$ Jumlah total kuadrat variabel $\mathrm{X}$

$\Sigma \mathrm{Y}^{2} \quad=$ Jumlah total kuadrat variabel $\mathrm{Y}$

$\mathrm{N}=$ Jumlah responden keseluruhan

4) Adapun untuk menilai interpretasi terhadap koefisien korelasi (nilai r) yang diperoleh yaitu dengan menggunakan tabel interpretasi sebagai berikut:

Tabel. 3.6

Nilai Interpretasi Angka Indeks Korelasi

\begin{tabular}{|c|c|}
\hline $\begin{array}{c}\text { Besarnya "r" } \\
\text { Product Moment } \\
\left(\mathbf{r}_{\mathbf{x y}}\right)\end{array}$ & \multicolumn{1}{|c|}{ Interpretasi } \\
\hline $0,00-0,20$ & $\begin{array}{l}\text { Antara variabel X dan variabel Y memang } \\
\text { terdapat korelasi, akan tetapi korelasi itu } \\
\text { sangat lemah atau sangat rendah sehingga } \\
\text { korelasi itu diabaikan (dianggap tidak ada } \\
\text { korelasi antara variabel X dan variabel Y }\end{array}$ \\
\hline $0,20-0,40$ & $\begin{array}{l}\text { Antara variabel X dan variabel Y terdapat } \\
\text { korelasi yang lemah atau rendah }\end{array}$ \\
\hline
\end{tabular}




\begin{tabular}{|c|l|}
$0,40-0,70$ & $\begin{array}{l}\text { Antara variabel X dan variabel Y terdapat } \\
\text { korelasi yang sedang atau cukupan }\end{array}$ \\
\hline $0,70-0,90$ & $\begin{array}{l}\text { Antara variabel X dan variabel Y terdapat } \\
\text { korelasi yang kuat atau tinggi }\end{array}$ \\
\hline $0,90-1,00$ & $\begin{array}{l}\text { Antara variabel X dan variabel Y terdapat } \\
\text { korelasi yang sangat kuat atau sangat tinggi }\end{array}$ \\
\hline
\end{tabular}

\section{d. Hipotesis Statistik}

Sugiyono mengemukakan bahwa Hipotesis merupakan jawaban sementara terhadap rumusan masalah penelitian, dimana rumusan masalah penelitian telah dinyatakan dalam benuk pertanyaan. ${ }^{14}$ Dikatakan sementara karena jawaban yang diberikan baru didasarkan pada teori yang relevan, belum didasarkan pada fakta-fakta empiris yang diperoleh melalui pengumpulan data.

Berdasarkan keterangan di atas, maka dapat dirumuskan hipotesis sebagai berikut:

Ho : Tidak terdapat kompetensi kepribadian guru dan pengaruhnya terhadap motivasi belajar bidang studi PAI siswa kelas X di SMA Ma'arif Bulakamba Kabupaten Brebes.

$H a$ : Terdapat hubungan kompetensi kepribadian guru dan pengaruhnya terhadap motivasi belajar bidang studi PAI siswa kelas X di SMA Ma’arif Bulakamba Kabupaten Brebes

Sebelum kita mengetahui adakah kompetensi kepribadian dengan motivasi belajar, maka penulis perlu mengetahui besarnya korelasi antara proses kompetensi kepribadian dengan motivasi belajar dapat diperoleh dengan menggunakan rumus korelasi product moment sebagai berikut:

Rumus korelasi product moment:

$$
r_{x y}=\frac{N \cdot \Sigma \mathrm{XY}-(\Sigma \mathrm{X})(\Sigma \mathrm{Y})}{\sqrt{\left\{N \cdot \Sigma \mathrm{X}^{2}-(\Sigma \mathrm{X})^{2}\right\}\left\{N \cdot \Sigma Y^{2}-(\Sigma Y)^{2}\right\}}}
$$

Keterangan:

${ }^{14}$ Sugiyono, Metode Penelitian Pendidikan, 96. 


$$
\begin{aligned}
& r_{x y}=\text { Angka indeks korelasi antara variabel } \mathrm{X} \text { dan } \mathrm{Y} \\
& \Sigma X Y=\text { Jumlah hasil perkalian antara skor } \mathrm{X} \text { dan skor } \mathrm{Y} \\
& \Sigma \mathrm{X}=\text { Jumlah total variabel } \mathrm{X} \\
& \Sigma \mathrm{Y}=\text { Jumlah total variabel } \mathrm{Y} \\
& \Sigma \mathrm{X}^{2}=\text { Jumlah total kuadrat variabel } \mathrm{X} \\
& \Sigma \mathrm{Y}^{2}=\text { Jumlah total kuadrat variabel } \mathrm{Y} \\
& \mathrm{N}=\text { Jumlah responden keseluruhan } \\
& r_{x y}=\frac{N \cdot \Sigma \mathrm{XY}-(\Sigma \mathrm{X})(\Sigma \mathrm{Y})}{\sqrt{\left\{N \cdot \Sigma \mathrm{X}^{2}-(\Sigma \mathrm{X})^{2}\right\}\left\{N \cdot \Sigma Y^{2}-(\Sigma Y)^{2}\right\}}} \\
& r_{x y}=\frac{57.63229-(2287)(1575)}{\sqrt{\left\{57.92489-(2287)^{2}\right\}\left\{57.44215-(1575)^{2}\right\}}} \\
& r_{x y}=\frac{3604053-3602025}{\sqrt{\{5271873-5230369\}\{2520255-2480625\}}} \\
& r_{x y}=\frac{2028}{\sqrt{\{41504\}\{39630\}}} \\
& r_{x y}=\frac{2028}{\sqrt{164480}} \\
& r_{x y}=\frac{2028}{40556} \\
& r_{x y}=0,050
\end{aligned}
$$

Berdasarkan perhitungan diatas diperoleh nilai koefisien anatar hubungan kompetensi kepribadian guru (varibel $\mathrm{x}$ ) dengan motivasi belajar siswa bidang studi PAI di SMA Ma'arif Bulakamba Kabupaten Brebes (variabel y) sebesar $\mathrm{r}_{\mathrm{xy}}=0,050$. Hasil tersebutdikonsultasikan pada indeks korelasi product moment (Sudjana, dkk.2005 : 100101) berada pada interval $0,40-0,70$ yang berarti memiliki tingkat hasil korelasi yang

\section{cukup tinggi/sedang.}

Nilai korelasi dari hasil perhitungan di atas, selanjutnya dihitung nilai koefesien determinasinya, untuk mengetahui besaran hubungan kompetensi kepribadian guru (variabel x) dengan motivasi belajar pada bidang studi PAI siswa kelas x SMA Ma'arif Bulakamba Kabupaten brebes (variabel y), rumusnya sebagai berikut : $r_{\text {hitung }} r_{\text {tabel }}$

$$
\begin{aligned}
\mathrm{KD} & =r^{2} \times 100 \% \\
& =0,050^{2} \times 100 \% \\
& =0,0025^{2} \times 100 \% \\
& =0,25 \%
\end{aligned}
$$


Hasil dari nilai koefesien determinasi di atas, menunjukan bahwa hubungan kompetensi kepribadian guru dengaiswa kelas $\mathrm{x}$ di motivasi belajar siswa kelas $\mathrm{x}$ SMA Ma'arif Bulakamba sebesar 0,25\% dan sisanya sebesar 99,75\%dipengaruhi oleh faktor lain yang tidak peneliti teliti dan dapat mempengaruhi motivasi belajar siswa, seperti faktor pergaulan, pertemanan, keluarga, dan lingkungan sekitar.

\section{Kesimpulan}

Berdasarkan hasil penelitian dan pembahasan penelitian, maka peneliti dapat mengambil beberapa kesimpulan yaitu sebagai berikut:

1. Kompetensi kepribadian guru di SMA Ma'arif Bulakamba Kabupaten Brebes dengan jumlah cukup tinggi atau sedang dan diperoleh hasil rata rata cukup tingg/sedang.

2. Motivasi belajar bidang studi PAI siwa kelas X di SMA Ma'arif Bulakamba Kabupaten Brebes degan jumlah cukup tinggi atau sedang dan diperoleh hasil rata rata cuku tinggi/sedang.

3. Hubungan antara kompetensi kepribadian guru dan pengaruuhnya terhadap motivasi belajar bidang studi PAI siswa kelas X di SMA Ma'arif Bulakamba Kabupaten Brebes memiliki tingkat korelasi yang cukup tinggi/sedang. Hal ini dapat dibuktikan dari perhitungan koefesien korelasi $\boldsymbol{r}_{\boldsymbol{x y}} \mathbf{0 , 0 5 0}$ yang berada pada interval 0,40-0,70. Hubungan anatara kompetensi kepribadian guru dan motivasi belajar sebesar $0,25 \%$ dan sisanya sebesar $99,75 \%$ di pengaruhi oleh faktor lain yang tidak peneliti teliti dan dapat mempengaruhi motivasi belajar siswa, seperti faktor pergaulan, pertemanan, keluarga, lingkungan sekitar,dan lain-lain. Artinya semakin baik kompetensi kepribadian guru akan berhubungan dengan motivasi belajar siswa. Demikian pula sebaliknya jika kompetensi kepribadian guru yang kurang baik akan mempengaruhi rendahnya motivasi belajar siswa. 


\section{DAFTAR PUSTAKA}

Arikunto, Suharsimi, 2006. Prosedur Penelitian; Suatu Pendekatan Praktik. Jakarta: PT Rineka Cipta.

Siregar, Eveline, dan Hartini Nara, 2011. Teori belajar dan Pembelajaran. Bogor: Ghalia Indonesia.

Musfah, Jejen, 2012 .Peningkatan Kompetensi Guru, Jakarta: Kencana Prenada Media Group.

Purwanto, Ngalim, 2013, Psikologi Pendidikan. Bandung: Remaja Rosdakarya.

Sardiman, 2011. Intraksi Dan Motivasi Belajar - Mengajar Jakarta.

Sugiyono, 2007. Metode Penelitian Pendidikan. Bandung: Alfabeta.

Sukmadinata, Nana Saodih, 2005. Landasan Psikologi Proses Pendidikan. Bandung : PT Remaja Rosda Karya. 